\title{
Acyclic indole and carbazole-based sulfate receptors
}

\author{
Philip A. Gale, ${ }^{*}, a$ Jennifer R. Hiscock, ${ }^{a}$ Chen Zhu Jie ${ }^{a, b}$ Michael B. Hursthouse ${ }^{a}$ and Mark E. Light ${ }^{a}$ \\ Received (in $X X X, X X X) X$ th $X X X X X X X X X 200 X$, Accepted Xth $X X X X X X X X X 200 X$ \\ First published on the web $X$ th $X X X X X X X X X 200 X$ \\ ${ }_{5}$ DOI: 10.1039/b000000x
}

The anion complexation properties of a series of acyclic receptors consisting of diindolylurea groups appended with amide, amidoindole or amidocarbazole groups have been studied. The receptors selectively bind and encapsulate sulfate via either six or eight hydrogen bonds. Receptors containing eight hydrogen bond donors perturb the $\mathrm{pKa}$ of bound dihydrogen phosphate and 10 bicarbonate to the extent that they are deprotonated by free anion in solution.

\section{Introduction}

The development of sulfate selective anion receptors is currently an area of intense interest due the important roles 15 this anion plays in biological systems and disease, ${ }^{1}$ in hydrometallurgy ${ }^{2}$ and as a pollutant. ${ }^{3}$ Tripodal tris-urea based systems have been developed by Custelcean and co-workers as selective receptors for $\mathrm{SO}_{4}{ }^{2-}$ with the goal of precipitating the anion from solution. ${ }^{4}$ These species form $2: 1$ 20 receptor:sulfate complexes binding the anion via twelve $\mathrm{NH}^{\cdots} \mathrm{O}$ hydrogen bonding interactions. Additionally Custelcean, Hay and co-workers have developed selfassembling urea containing cage systems to arrange six urea groups around sulfate. ${ }^{5}$ Sulfate has also been employed by ${ }_{25}$ Beer and co-workers in to assemble a variety of interlocked structures. ${ }^{6}$ Macrocyclic sulfate receptors include Sessler's cyclo[8]pyrrole ${ }^{7}$, Bowman-James' cyclic tetraamide/amine based receptor ${ }^{8}$ that forms a sandwich complex with $\mathrm{SO}_{4}{ }^{2-}$ and Kubik's cyclic peptide based molecular oysters. ${ }^{9}$

30 Despite the anion complexation properties of indole being recognised in biological systems, ${ }^{10}$ it was not until $2004^{11}$ and $2005^{12}$ that the first reports of the use of indole in synthetic anion receptors appeared. Since then indole has been employed in a number of receptor systems ${ }^{13}$ including a 35 variety of foldamers reported by Jeong and co-workers that exhibit conformational changes in the presence of particular anions. ${ }^{14}$ Taking inspiration from this latter work, we decided to synthesise linear receptors that could wrap around tetrahedral oxo-anions such as sulfate but that would possess 40 lower affinities for anions possessing other geometries.

We have previously shown that diindolylureas form $3: 1$ complexes with $\mathrm{PO}_{4}{ }^{3-}$ (binding the anion via twelve hydrogen bonds) ${ }^{15}$ in the solid state and in the process drive the deprotonation of the anion. ${ }^{16}$ In this paper we report the 45 synthesis of receptors $\mathbf{1}$ and $\mathbf{2}$ that contain pendant amidoindole and amido-carbazole groups and their interaction with a range of anionic guests. These compounds are designed to selectively bind sulfate over chloride (due to the large size of the binding site) or carboxylates (due the the carboxylate 50 anion being saturated by four hydrogen bonds from the diindolylurea skeleton ${ }^{15}$ ). We compared the anion complexation properties of these species with compound $\mathbf{3}^{16}$ which contains pendant phenyl amides and a total of six hydrogen bond donor groups.

\section{${ }_{55}$ Results and Discussion}

\section{Synthesis}

7-Nitroindole-2-carboxylic acid was coupled to either 7aminoindole or 1-aminocarbazole using pyBOP as an amide coupling reagent in DMF. The resulting amides were reduced 60 from nitro- to amine derivatives using $10 \% \mathrm{Pd} / \mathrm{C}$ under an hydrogen atmosphere in DMF and the resulting amines coupled using triphosgene in a mixture of chloroform, DMF and saturated sodium bicarbonate solution to afford compounds 1 and $\mathbf{2}$ in 29\% and 55\% respective overall yields. ${ }_{65}$ Compound $\mathbf{3}$ was synthesised using literature methods. ${ }^{16}$

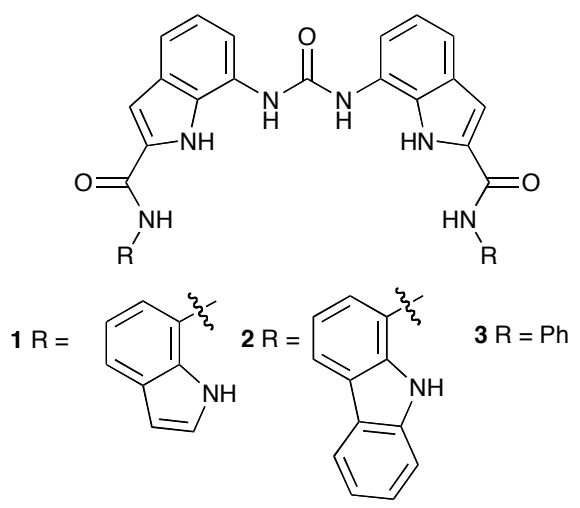

\section{Crystallography}

Initial anion complexation studies were conduced using single 70 crystal X-ray diffraction. Crystals of the tetrabutylammonium benzoate complex of receptor $\mathbf{1}$ were obtained by slow evaporation from a DMSO solution containing excess tetrabutylammonium benzoate. The structure (Figure 1) reveals that receptor 1 binds three equivalents of benzoate in 75 the solid state. The central diindolylurea group binds one benzoate anion via four hydrogen bonds N3 ${ }^{\cdots} \mathrm{O} 66$ 2.719(4) $\AA$;

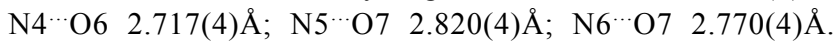
The pendant amidoindole groups are oriented out of the cavity with each binding a single equivalent of benzoate via two or

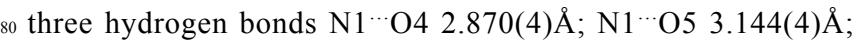




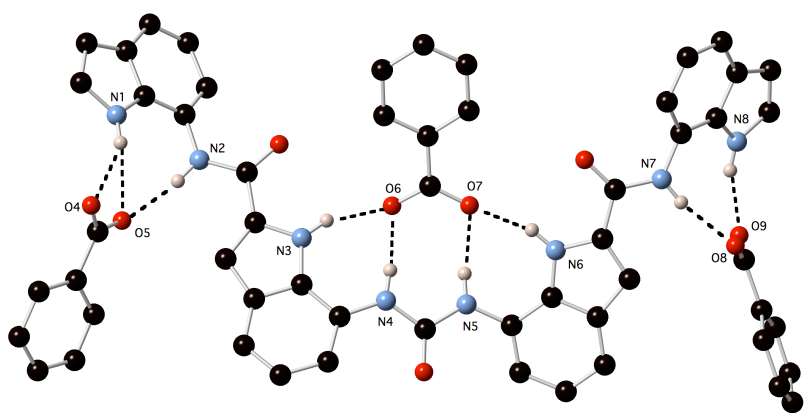

Figure 1 The X-ray crystal structure of 1 . (TBA $)_{3}\left(\mathrm{C}_{6} \mathrm{H}_{5} \mathrm{CO}_{2}\right) \cdot \mathrm{H}_{2} \mathrm{O}$ Tetrabutylammonium counter cations and water omitted for clarity.

Crystals of the monohydrogen phosphate complex of receptor 1 were obtained by slow evaporation of a DMSO solution of 10 the receptor in the presence of excess tetrabutylammonium dihydrogen phosphate. The structure (Figure 2) shows the monohydrogen phosphate anion bound by nine hydrogen bonds from the receptor: $\mathrm{N} 1 \cdots \mathrm{O} 7$ 2.970(8) $\AA$; $\mathrm{N} 1{ }^{\cdots} \mathrm{O} 4$ $3.109(7) \AA ; \quad \mathrm{N} 2 \cdots \mathrm{O} 4 \quad 2.790(8) \AA ; \mathrm{N} 3 \cdots \mathrm{O} 4 \quad 2.736(8) \AA ; \mathrm{N} 4 \cdots \mathrm{O} 5$

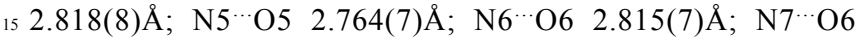

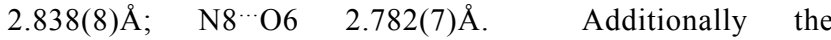
monohydrogen phosphate dimerise in the solid state via two hydrogen bonds $\mathrm{O} 7{ }^{\cdots} \mathrm{O} 5^{\mathrm{i}}$ and $\mathrm{O} 7^{\mathrm{i}} \ldots \mathrm{O} 5$ 2.645(7) $\AA$ the symmetry transformation $-\mathrm{x}+1,-\mathrm{y}+1,-\mathrm{z}$ generates atoms 20 labelled (i). We have previously observed deprotonation of dihydrogenphosphate bound to neutral diindolylurea based receptors due to the multiple hydrogen bonding interactions lowering the $\mathrm{pKa}$ of the bound guest to the extent that it is deprotonated by free dihydrogen phosphate in solution and we ${ }_{25}$ suggest that the same process occurs here. ${ }^{16}$
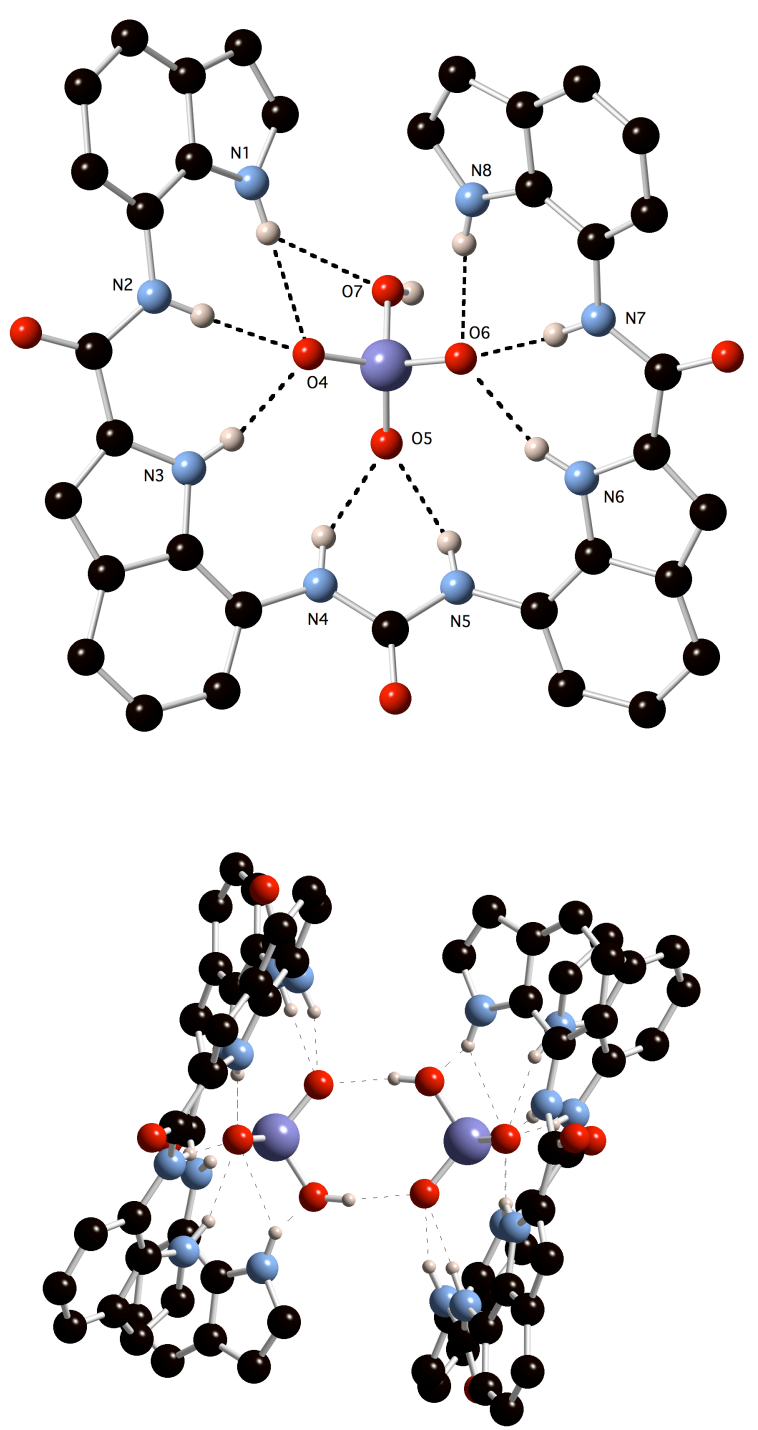

Figure 2 Two views of the X-ray crystal structure of 1 .(TBA) $\left(\mathrm{HPO}_{4}\right)$ Tetrabutylammonium counter cations have been omitted for clarity.

${ }_{40}$ Crystals of the tetrabutylammonium sulfate complex of receptor 1 were obtained by slow evaporation of a DMSO solution of the receptor in the presence of excess terabutylammonium sulfate. ${ }^{17}$ The structure (Figure 3 ) reveals that the anion is bound by eight hydrogen bonds from the

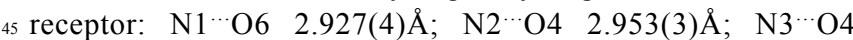

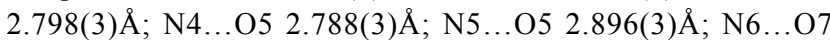

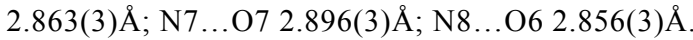



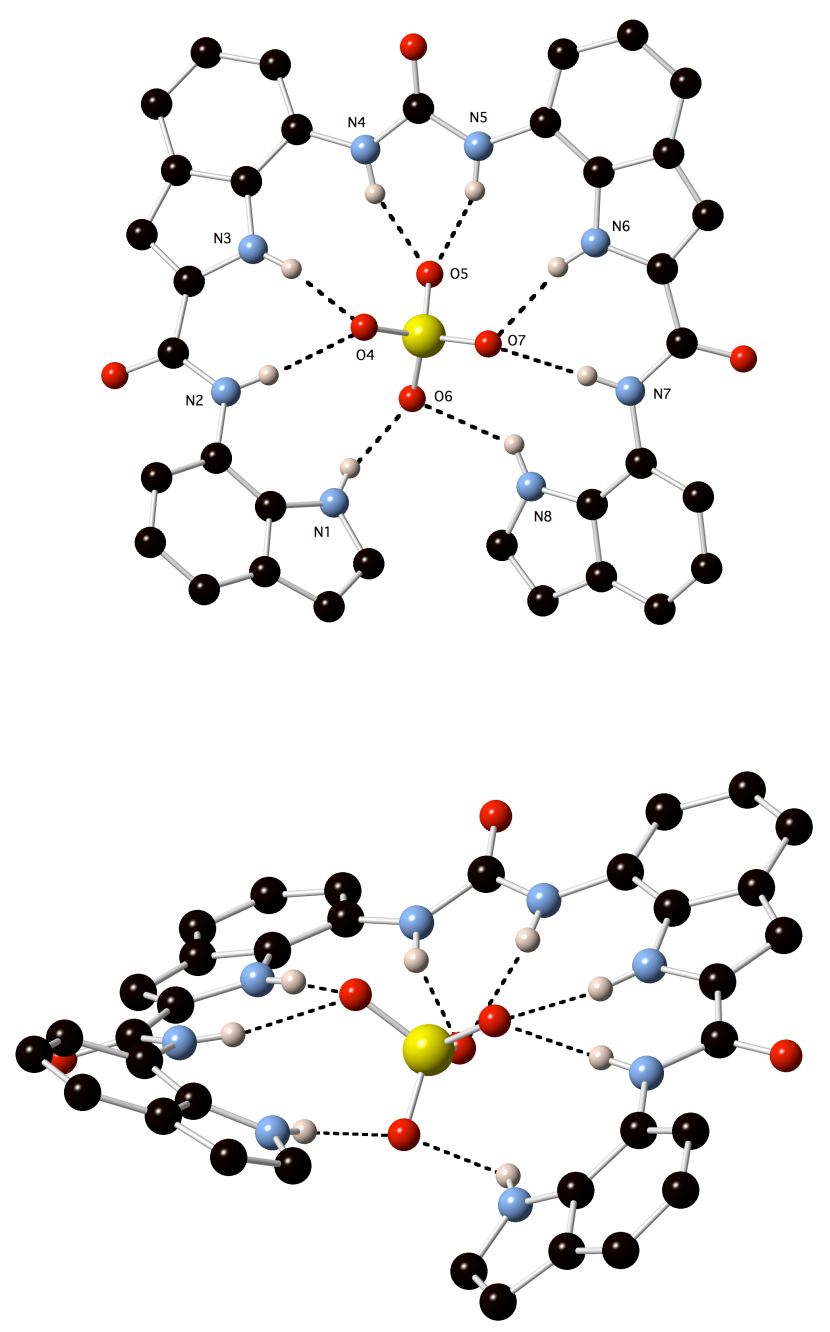

Figure 3 Two views of the X-ray crystal structure of $1(\mathrm{TBA})_{2} \mathrm{SO}_{4}$. Tetrabutylammonium counter cations have been omitted for clarity.

\section{Solution studies}

The solution anion binding properties of compounds $\mathbf{1}$ and $\mathbf{2}$ were studied by ${ }^{1} \mathrm{H}$ NMR titration techniques in DMSO$d_{6} /$ water mixtures and compared to those of compound 3. ${ }_{10}$ Initial ${ }^{1} \mathrm{H}$ NMR titration studies were conducted in DMSO$d_{6} / 0.5 \%$ water. The NMR titrations with compounds $\mathbf{1}-\mathbf{3}$ with acetate are shown in Figure 4. The results show that the $\mathrm{NH}$ groups in the central diindolylurea unit in these three compounds bind the first equivalent of acetate added to

15 solution. Futher aliquots of acetate bind to the pendant amide or pendant amide and/or indole or carbazole groups (as shown in Scheme 1 for compound 1). This can be seen clearly in the NMR titration curves for compounds $\mathbf{1}$ and $\mathbf{2}$ wherein the pendant $\mathrm{NH}$ groups begin to shift downfield after the addition 20 of 1.0 equivalents of acetate. In the case of compound $\mathbf{2}$, it appears that more complex equilibria are present as after the addition of three equivalents of acetate, the central indole groups begin to shift downfield again after having previously reached a plateau. This process does not occur in DMSO-
${ }_{25} d_{6} / 10 \%$ water (Figure 5). Similar sequential binding of anions to simple urea-amide receptors containing multiple hydrogen bond donor groups has been observed previously by Gunnlaugsson and co-workers. ${ }^{18}$ Analgous titration experiments with compounds 1 and 2 in DMSO- $d_{6} / 0.5 \%$ water 30 resulted in precipitation.
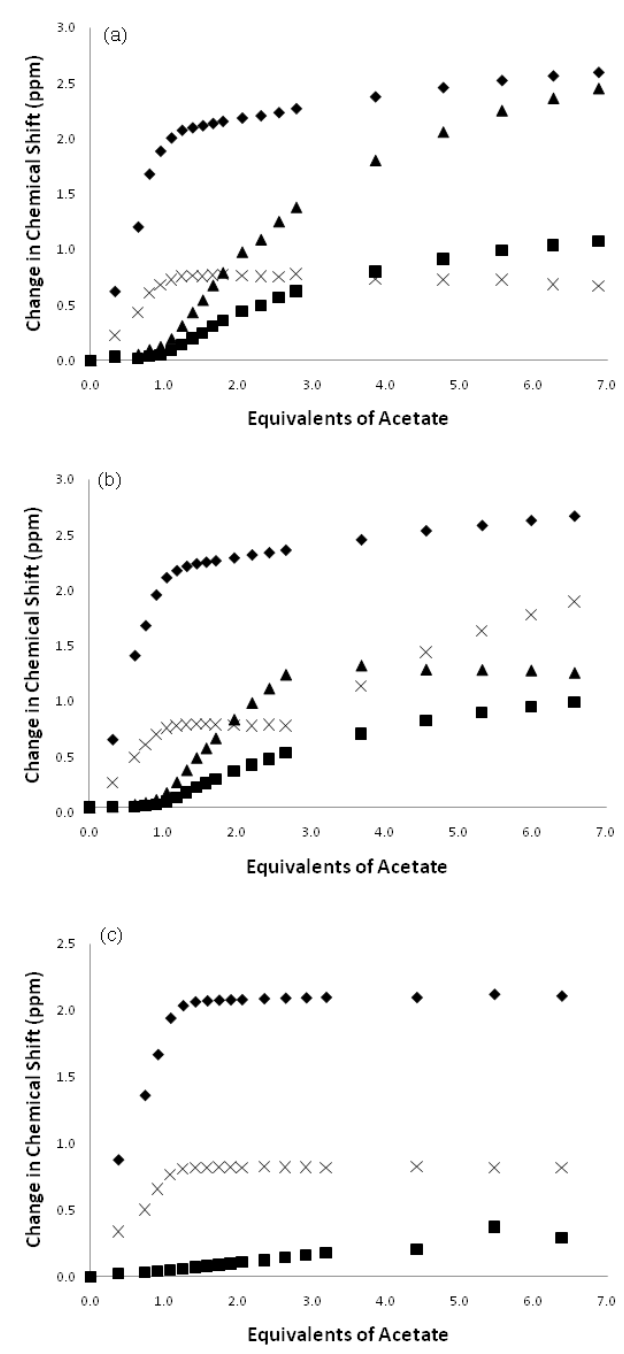

Figure 4 Proton NMR titration data for compounds 1 (a), 2 (b) and $\mathbf{3}$ (c) 35 upon addition of tetrabutylammonium acetate in DMSO- $d_{6} / 0.5 \%$ water solution. (Key: $=$ urea $\mathrm{NH} ; \mathbf{\square}=$ amide $\mathrm{NH} ; \mathbf{x}=$ indole $\mathrm{NH}$ (adjacent to urea); $\boldsymbol{\Delta}$ = pendant indole or carbazole $\mathrm{NH})$. 


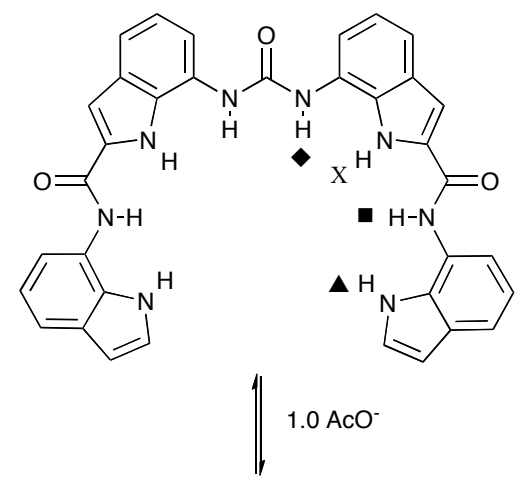<smiles></smiles><smiles>CC(=O)OCc1cc2cccc(NC(=O)Nc3cccc4cc(C(=O)Nc5cccc6cc[nH]c56)n(C)c34)c2n1COC(C)=O</smiles>

Scheme 1 Proposed solution equilibria of compound $\mathbf{1}$ with acetate in DMSO- $\mathrm{d}_{6} /$ water solution.
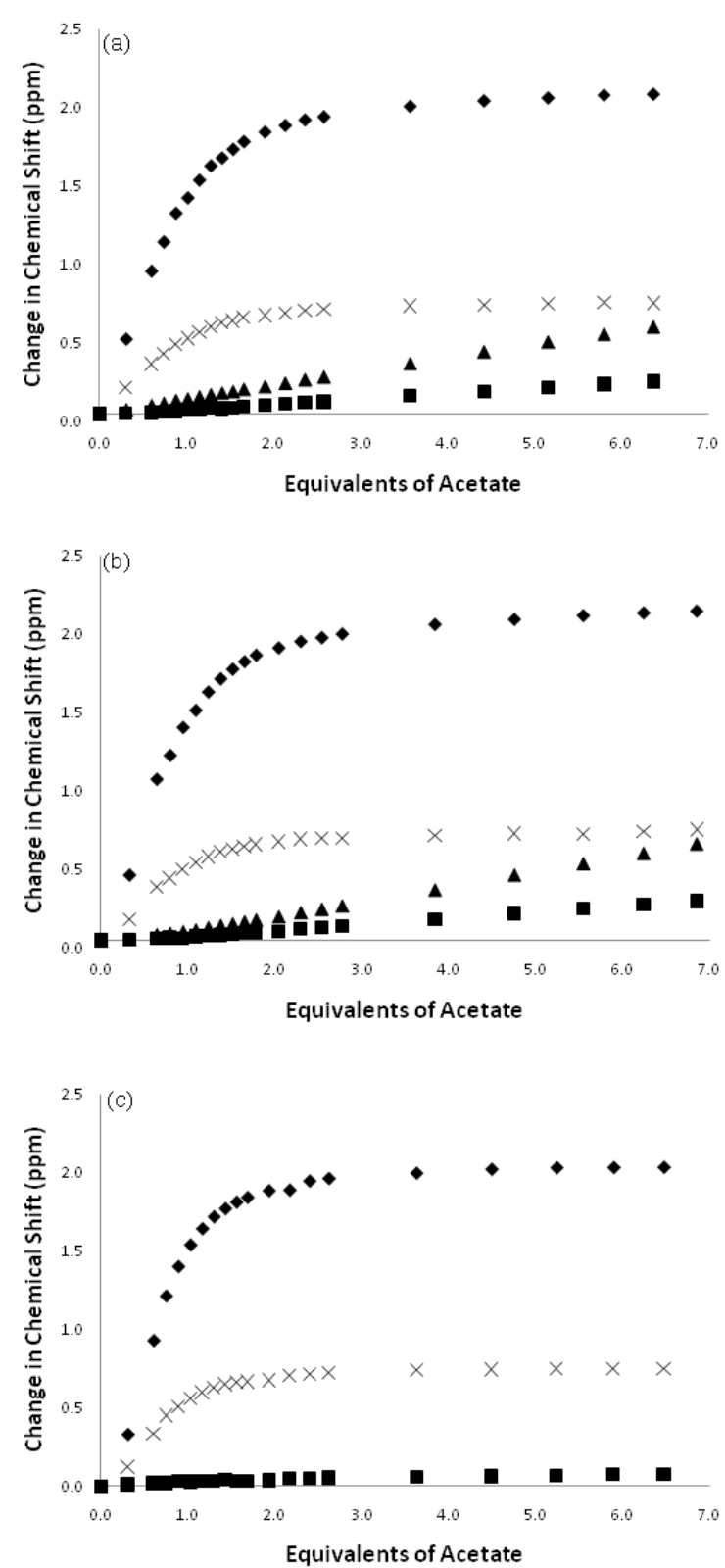

5 Figure 5 Proton NMR titration data for compounds $\mathbf{1}$ (a), 2 (b) and $\mathbf{3}$ (c) upon addition of tetrabutylammonium acetate in DMSO- $d_{6} / 10 \%$ water solution. (Key: $\boldsymbol{\nabla}=$ urea $\mathrm{NH} ; \boldsymbol{\square}=$ amide $\mathrm{NH} ; \mathbf{X}=$ indole $\mathrm{NH}$ (adjacent to urea); $\boldsymbol{\Delta}$ = pendant indole or carbazole $\mathrm{NH}$ ).

10 In contrast to the results found with acetate, addition of tetrabutylammonium sulfate causes all the $\mathrm{NH}$ groups in compounds 1, 2 and $\mathbf{3}$ to shift downfield upon addition substoichiometric quantities of the anion. The NMR titration data conducted in DMSO- $d_{6} / 0.5 \%$ water is shown in Figure 6.

${ }_{15}$ Compound 3 binds sulfate strongly in 1:1 stoichiometry with a stability constant $>10^{4} \mathrm{M}^{-1}$ under these conditions. Upon addition of sulfate to compounds $\mathbf{1}$ and $\mathbf{2}$, more complex equilibria are observed. The NMR titration curves show a discontinuity at one equivalent of sulfate which may be 20 indicative of initial formation of a 1:1 complex followed by a conformational rearrangement and formation of higher order complexes. However, just as was observed with acetate, 
moving to DMSO- $d_{\sigma} / 10 \%$ water reduces the complexity of the equlibria in solution with predominant $1: 1$ complex formation and an apparent stability constant $>10^{4} \mathrm{M}^{-1}$ for sulfate with compound 2 under these competitive conditions (Figure 7). ${ }_{5}$ Interestingly both compounds $\mathbf{1}$ and $\mathbf{3}$ crystallise over the course of about 20 minutes upon addition of tetrabutylammonium sulfate to DMSO- $d_{6} / 10 \%$ water solutions of the receptors. This unfortunately precluded conducting NMR titrations under these conditions. The same process 10 occurs more slowly with compound 2 . The DMSO- $d_{6} / 10 \%$ water solution of compound 1 after addition of 15 equivalents of tetrabutylammonium sulfate is shown in Figure 8.
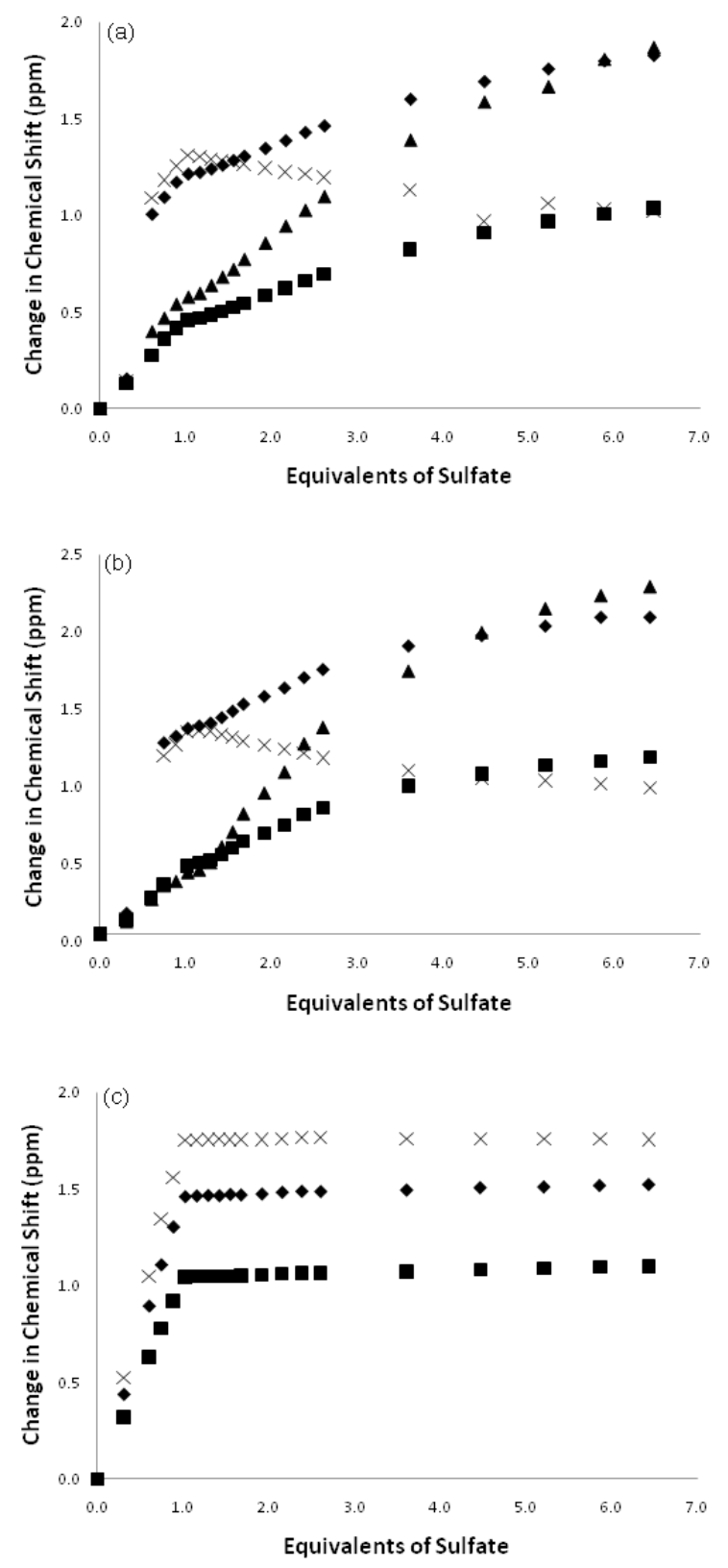

Figure 6 Proton NMR titration data for compounds 1 (a), 2 (b) and 3 (c) 15 upon addition of tetrabutylammonium sulfate in DMSO- $d_{6} / 0.5 \%$ water solution. (Key: $>$ = urea NH; $=$ amide $\mathrm{NH} ; \boldsymbol{X}=$ indole $\mathrm{NH}$ (adjacent to urea); $\boldsymbol{\Delta}$ = pendant indole or carbazole $\mathrm{NH}$ ).

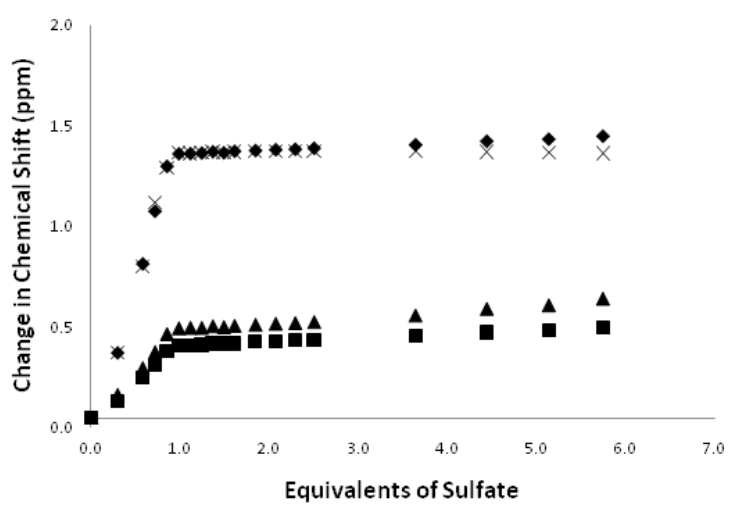

Figure 7 Proton NMR titration data for compounds 2 upon addition of 20 tetrabutylammonium sulfate in DMSO- $d_{6} / 10 \%$ water solution. (Key: $\bullet=$ urea $\mathrm{NH} ; \boldsymbol{\square}=$ amide $\mathrm{NH} ; \mathbf{x}=$ indole $\mathrm{NH} ; \boldsymbol{\Delta}$ = pendant carbazole $\mathrm{NH}$ ).

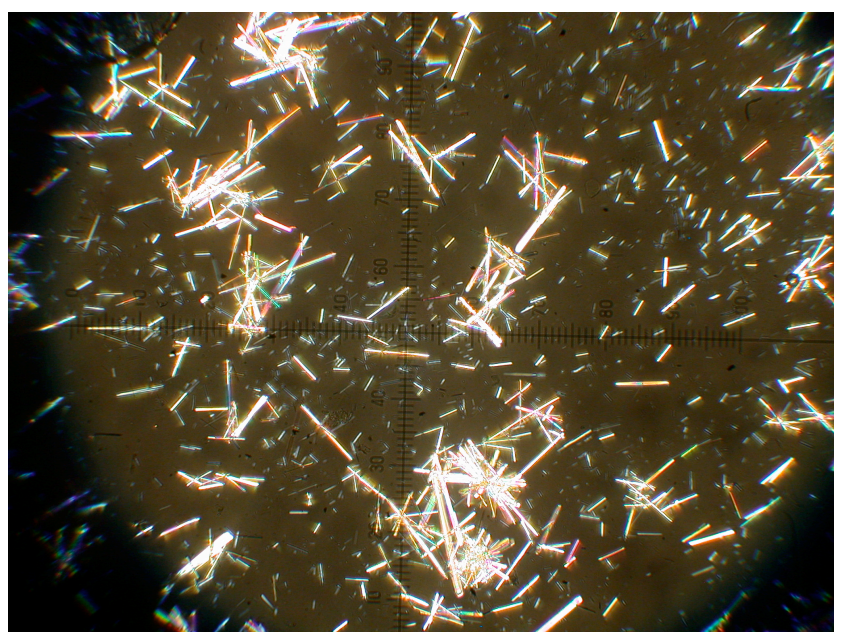

Figure $8 \mathrm{~A}$ view of the DMSO- $d_{6} / 10 \%$ water solution of compound $\mathbf{1}$ in the presence of 15 equivalents of tetrabutylammonium sulfate. Crystals 25 form approximately 20 minutes after the addition of sulfate.

By following the change in chemical shift of the urea $\mathrm{NH}$ groups in DMSO- $d_{6} / 10 \%$ it is possible to calculate apparent stability constants $600 \mathrm{M}^{-1}$ and $690 \mathrm{M}^{-1}$ for the complexation of the first equivalent of acetate by compounds $\mathbf{1}$ and $\mathbf{2}$. 30 Stability constants of $120 \mathrm{M}^{-1}$ and $315 \mathrm{M}^{-1}$ for compounds $\mathbf{1}$ and 2 with tetrabutylammonium dihydrogen phosphate in DMSO- $d_{6} / 10 \%$ water were also measured. Addition of tetrabutylammonium chloride or hydrogen sulfate to both compounds in DMSO- $d_{6} / 0.5 \%$ water resulted in only very 35 small perturbations of the NMR spectra. Compound 3 binds dihydrogen phosphate with a stability constant of $107 \mathrm{M}^{-1}$ in $0.5 \%$ water and acetate with a stability constant of $8460 \mathrm{M}^{-1} .{ }^{16}$ In all cases these stability constants were calculated following the shift of the urea NH groups using the EQNMR computer 40 program. ${ }^{19}$

In DMSO- $d_{6} / 0.5 \%$ water, behaviour indicative of deprotonation of the bound anionic guest was observed with compounds 1 and $\mathbf{2}$ upon addition of dihydrogen phosphate and bicarbonate (with the latter anion added as the 45 tetraethylammonium salt), i.e. new peaks appear in the NMR spectrum shifted significantly downfield from the free ligand due to formation of monohydrogen phosphate or carbonate 
complexes. This results from multiple hydrogen bonding interactions to the bound guest from the receptor reducing the $\mathrm{pKa}$ of the anion and subsequent deprotonation by free anion in solution. ${ }^{13}$ Deprotonation was confirmed by addition of 5 one equivalent of the anionic guest followed by hydroxide which results in the appearance of the same new NMR resonances. This is shown in Figure 9 for compound $\mathbf{1}$ and tetrabutylammonium dihydrogen phosphate. In $10 \%$ water this was observed only upon addition of $\mathrm{HCO}_{3}{ }^{-}$but not $\mathrm{H}_{2} \mathrm{PO}_{4}{ }^{-}$ 10 (see ESI for more details).

Table 1 Stability constants $\left(K_{a} / \mathrm{M}^{-1}\right)$ of compounds $\mathbf{1}, \mathbf{2}$ and $\mathbf{3}$ with a variety of putative anionic guests ${ }^{a}$ determined by ${ }^{1} \mathrm{H}$ NMR titration techniques in DMSO- $d_{6} / 10 \%$ water mixtures at $298 \mathrm{~K}$ following the urea $15 \mathrm{NH}$ group resonance. Errors $<15 \%$.

\begin{tabular}{|c|c|c|c|}
\hline \multirow[t]{2}{*}{ Anion } & \multicolumn{2}{|c|}{ Compounds } & \multirow[b]{2}{*}{$\mathbf{3}^{g}$} \\
\hline & 1 & 2 & \\
\hline${ }_{20} \mathrm{Cl}^{-}$ & $b$ & $b$ & n.d. \\
\hline $\mathrm{HSO}_{4}^{-}$ & $b$ & $b$ & n.d. \\
\hline $\mathrm{AcO}^{-}$ & $600^{\mathrm{c}}$ & $690^{c}$ & 1422 \\
\hline 25 & & & \\
\hline $\mathrm{BzO}^{-}$ & n.d. & n.d. & 481 \\
\hline $\mathrm{H}_{2} \mathrm{PO}_{4}^{-}$ & 120 & 315 & $d$ \\
\hline $30 \mathrm{HCO}_{3}^{-}$ & $e$ & $e$ & $f$ \\
\hline
\end{tabular}

$a$ Anions added as tetrabutylammonium salts except bicarbonate which was added as the tetraethylammonium salt. $b$ Only small perturbations were observed in the ${ }^{1} \mathrm{H}$ NMR spectrum upon addition of these anions. $c$ ${ }_{35} K_{l}$ values reported only. $d$ Isotherm could not be fitted to a $1: 1$ or $1: 2$ binding model. $e$ Deprotonation of bound guest was observed. $f$ Peak broadening prevented an stability constant from being determined in this case (possibly due to deprotonation of the bound guest). $g$ Data from reference 16 .

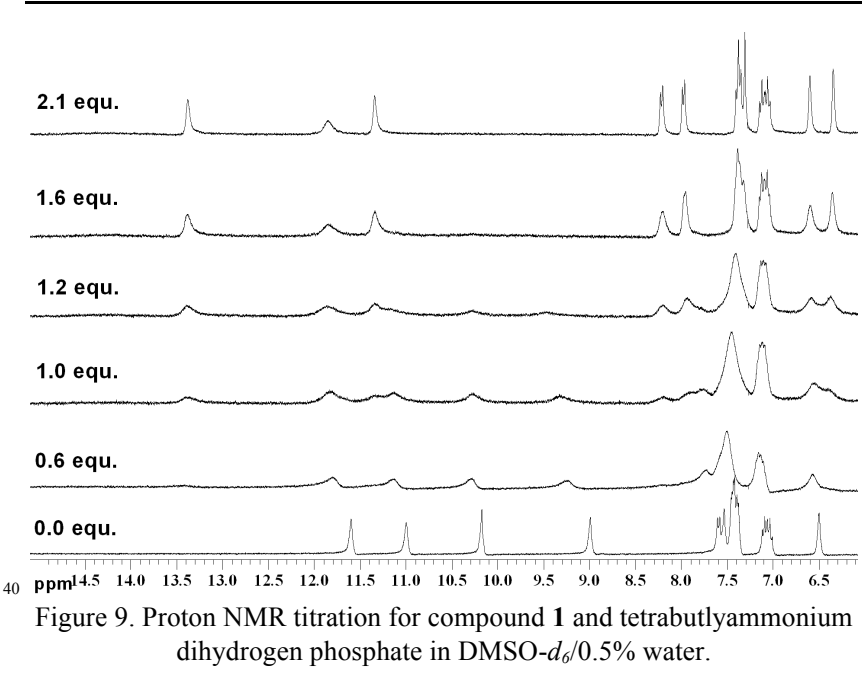

\section{Conclusions}

Compounds $\mathbf{1}-\mathbf{3}$ all bind sulfate strongly in DMSO- $d_{6} / 0.5 \%$ 45 water. Under these conditions compound 3 forms a $1: 1$ complex whilst the NMR titration evidence leads us to suggest that compounds $\mathbf{1}$ and $\mathbf{2}$ also form 1:1 complexes but at higher sulfate concentrations there are multiple equilibria present. These additional processes do not occur in DMSO- $d_{6} / 10 \%$ so water to the same extent with predominant 1:1 complex formation. Hence by chaning the solvent conditions from $0.5 \%$ water to $10 \%$ water we have reduced the complexity of the equilibria present. Compound $\mathbf{2}$ binds sulfate with a stability constant $>10^{4} \mathrm{M}^{-1}$ under these conditions whilst 55 compounds $\mathbf{1}$ and $\mathbf{3}$ crystallise upon addition of sulfate. It's interesting to note that compound $\mathbf{3}$ binds sulfate strongly despite having two fewer hydrogen bond donors than compounds $\mathbf{1}$ and 2. The receptors are also capable of perturbing the $\mathrm{pKa}$ of bound dihydrogen phosphate or ${ }_{60}$ bicarbonate to the extent that they are deprotonated by free anions in solution. The crystal structures show that compound $\mathbf{1}$ is capable of encapsulating tetrahedral oxo-anions via eight hydrogen bonds. We are currently exploring the extraction properties of this new family of sulfate selective ${ }_{65}$ anionophores. The results of these studies will be reported in due course.

\section{Acknowledgements}

PAG thanks the EPSRC for funding and for access to the crystallographic facilities at the University of Southampton.

\section{${ }_{70}$ Notes and references}

${ }^{a}$ School of Chemistry, University of Southampton, Southampton, SO17 IBJ, UK. E-mail: philip.gale@soton.ac.uk; Fax: +44 (0)2380596805; Tel:+ 44 (0) 2380593332

${ }^{b}$ Raffles Institution (Junior College), One Raffles Institution Lane, 75 Singapore 575954. Tel: +65 64199888

$\dagger$ Electronic Supplementary Information (ESI) available: [experimental details, characterisation data for compounds 1 and 2, NMR and titration data]. See DOI: 10.1039/b000000x/

- Crystal data for compound (1.(TBA) $)_{2}\left(\mathrm{HPO}_{4}\right) \mathrm{C}_{67} \mathrm{H}_{99} \mathrm{~N}_{10} \mathrm{O}_{7} \mathrm{P}, \mathrm{Mr}=$ $801187.53, \mathrm{~T}=120(2) \mathrm{K}$, Monoclinic space group $P 2_{1} / n, \quad a=14.7860(6), b$ $=17.7836(6), c=25.6491(10) \AA, \beta=103.512(2)^{\circ} \mathrm{V}=6557.7(4) \AA^{3}, \rho_{\text {calc }}$ $=1.203 \mathrm{Mg} / \mathrm{m}^{3}, \mu=0.102 \mathrm{~mm}^{-1}, \mathrm{Z}=4$, reflections collected: 63501 , independent reflections: $11548\left(R_{\text {int }}==0.1856\right)$, final $R$ indices $[I>2 \sigma I]$ : $R 1=0.1595, w R 2=0.2338, R$ indices (all data): $R 1=0.2672, w R 2=$ 850.2775 .

+ Crystal data for compound (1. (TBA) $\left.{ }_{3}\left(\mathrm{C}_{6} \mathrm{H}_{5} \mathrm{CO}_{2}\right) \cdot \mathrm{H}_{2} \mathrm{O}\right) \mathrm{C}_{104} \mathrm{H}_{151} \mathrm{~N}_{11} \mathrm{O}_{10}$ $\mathrm{Mr}=1715.36, \mathrm{~T}=120(2) \mathrm{K}$, Triclinic space group $\mathrm{P} 1, a=8.9320(1), b=$ 12.4500(2), $c=22.5830(4) \AA, \alpha=93.6790(9)^{\circ}, \beta=100.5490(12)^{\circ}, \gamma=$ 98.6400(11) $)^{\circ} V=2429.96(6) \AA^{3}, \rho_{\text {calc }}=1.172 \mathrm{Mg} / \mathrm{m}^{3}, \mu=0.075 \mathrm{~mm}^{-1}$, ${ }_{90} \mathrm{Z}=1$, reflections collected: 38462 , independent reflections: $8540\left(R_{\mathrm{int}}=\right.$ $0.0637)$, final $R$ indices $[I>2 \sigma I]: R 1=0.0613, w R 2=0.1183, R$ indices (all data): $R 1=0.0811, w R 2=0.1288$.

$\S$ Crystal data for compound (1.(TBA) $)_{2}\left(\mathrm{SO}_{4}\right) \quad \mathrm{C}_{67} \mathrm{H}_{98} \mathrm{~N}_{10} \mathrm{O}_{7} \mathrm{~S}, \mathrm{Mr}=$ $1187.61, \mathrm{~T}=120(2) \mathrm{K}$, Triclinic space group P-1, $a=8.78020(10), b=$ $9516.9156(4) c=22.1638(5) \AA, \alpha=88.1703(11)^{\circ}, \beta=85.7351(12)^{\circ}, \gamma=$ $82.7653(13)^{\circ}, V=3255.72(11) \AA^{3}, \rho_{\text {calc }}=1.211 \mathrm{Mg} / \mathrm{m}^{3}, \mu=0.110 \mathrm{~mm}^{-1}$, $\mathrm{Z}=2$, reflections collected: 61520 , independent reflections: $11472\left(R_{\mathrm{int}}=\right.$ $0.0907)$, final $R$ indices $[I>2 \sigma I]: R 1=0.0734, w R 2=0.1616, R$ indices 100

1. H. Xu, N. Sträter, W. Schröder, C. Böttcher, K. Ludwing and W. Saenger, Acta Cryst., 2003, D59, 815-822; J.W. Pflugrath and F.A. Quiocho, Nature, 1985, 314, 257-260; J.W. Pflugrath and F.A Quiocho, J. Mol. Biol., 1988, 200, 163-180; D.E.C. Cole, R.M. Hanning, S.H. Zlotkin, W. Balfe, Nephron, 1986, 44, 186-190; R.M. Freeman and C.J. Richards, Kidney International 1979, 15, 167-175. 
2. S.G. Galbraith, Q. Wang, L, Li, A.J. Blake, C. Wilson, S.R. Collinson, L.F. Lindoy, P.G. Plieger, M. Schroder and P.A. Tasker, Chem. Eur. J. 2007, 13, 6091-6107; S.G. Galbraith and P.A. Tasker, Supramol. Chem. 2005, 17, 191-207; P.G. Plieger, P.A. Tasker and S.G. Galbraith, Dalton Trans. 2004, 313-318.

3. B.A. Moyer, L.H. Delmau, C.J. Fowler, A. Ruas, D.A. Bostick, J.L. Sessler, E. Katayev, G.D. Pantos, J.M. Llinares, Md. A. Hossain, S.O. Kang, and K. Bowman-James, in Advances in Inorganic Chemistry: Templates Effects and Molecular Organisation, (Volume

10 59) Eds. R. van Eldik and K. Bowman-James, Academic Press, London, 2007 pp175-204.

4. R. Custelcean, B. A. Moyer and B. P. Hay, Chem. Commun., 2005, 5971-5973; R. Custelcean, P. Remy, Bonnesen, D. Jiang and B. A. Moyer, Angew. Chem. Int. Ed., 2008, 47, 1866-1870. This class of

15 sulfate receptor has also been studied by other groups: B. Wu, J. J. Liang, J. Yang, C. D. Jia, X. J. Yang, H. R. Zhang, N. Tang and C. Janiak, Chem. Commun., 2008, 1762-1764; F. Y. Zhuge, B. A. Wu, J. J. Liang, J. Yang, Y. Y. Liu, C. D. Jia, C. Janiak, N. Tang and X. J. Yang, Inorg. Chem., 2009, 48, 10249-10256.

205. R. Custelcean, J. Barsano, P. V. Bonnesen, V. Kertesz and B. P. Hay, Angew. Chem. Int. Ed., 2009, 48, 4025-4029.

6. K.M. Mullen and P.D. Beer, Chem. Soc. Rev. 2009, 38, 1701-1713.

7. L.R. Eller, M. Stepien, C.J. Fowler, J.T. Lee, J.L. Sessler and B.A. Moyer, J. Am. Chem. Soc. 2007, 129, 11020-11021.

25 8. Md. A. Hossain, J.M. Llinares, D. Powell and K. Bowman-James, Inorg. Chem. 2001, 40, 2936-2937.

9. S. Kubik, R. Kirchner, D. Nolting and J. Seidel, J. Am. Chem. Soc. 2002, 124, 12752-12760; S. Otto and S. Kubik, J. Am. Chem. Soc. 2003, 125, 7804; Z. Rodriguez-Docampo, S.I. Pascu, S. Kubik and S. Otto, J. Am. Chem. Soc. 2006, 128, 11206.

10. K.H.G. Verschueren, F. Seljee, H.J. Rozeboom, K.H Kalk, and B.W. Dijkstra, Nature, 1993, 363, 693-698; J.J. He and F.A. Quiocho, Science, 1991, 251, 1479-1481.

11. M.J. Chmielewski, M. Charon and J. Jurczak, Org. Lett. 2004, 6,

35 3501-3504; P. Piatek, V.M. Lynch and J. L. Sessler, J. Am. Chem. Soc. 2004, 126, 16073-16076.

12. D. Curiel, A. Cowley and P.D. Beer, Chem. Commun. 2005, 236-238; K.-J. Chang, D. Moon, M.S. Lah and K.S. Jeong, Angew. Chem. Int. Ed. 2005, 44, 7926-7929.

40 13. J.-m. Suk, M. K. Chae, N.-K. Kim, U.-1 Kim and K.-S. Jeong, Pure Appl. Chem. 2008, 80, 599-608.; P.A. Gale, Chem. Commun. 2008, 4525-4540; C. Caltagirone and P.A. Gale, Chem. Soc. Rev., 2009, 38, 520-563; P.A. Gale, S.E. García-Garrido and J. Garric, Chem. Soc. Rev. 2008, 37, 151-190.

45 14. K.-J. Chang, B.-N. Kang, M.-H. Lee and K.-S. Jeong, J. Am. Chem. Soc. 2005, 127, 12214-12215; J.-m. Suk and K.-S. Jeong, J. Am. Chem. Soc. 2008, 130, 11868-11869; J. Kim, H. Juwarker, X. Liu, M.S. Lah and K.S. Jeong, Chem. Commun. 2010, 46, 764-766.

15. C. Caltagirone, P.A. Gale, J.R. Hiscock, S.J. Brooks, M.B

50 Hursthouse and M.E. Light, Chem. Commun. 2008, 3007-3009; C. Caltagirone, J.R. Hiscock, M.B. Hursthouse, M.E. Light and P.A. Gale, Chem. Eur. J., 2008, 14, 10236-10243. For carbazole analogues see: J.R. Hiscock, C. Caltagirone, M.E. Light, M.B. Hursthouse and P.A. Gale, Org. Biomol. Chem. 2009, 7, 1781-1783 and for our earlier work on indole see: G.W. Bates, P.A. Gale and M.E. Light, Chem. Commun. 2007, 2121-2123 and G.W. Bates, Triyanti, M.E. Light, M. Albrecht and P.A. Gale, J. Org. Chem. 2007, 72, 89218927. For related work by Caltagirone and co-workers see: C. Caltagirone, A. Mulas, F. Isaia, V. Lippolis, P.A. Gale and M.E. Light, Chem. Commun. 2009, 6279-6281.

16. P.A. Gale, J.R. Hiscock, S.J. Moore, C. Caltagirone, M.B. Hursthouse and M.E. Light, Chem. Asian J., 2010, 5, 555-561.

17. M.J. Chmielewski, L. Zhao, A. Brown, D. Curiel, M.R. Sambrook, A.L. Thompson, S.M. Santos, V. Felix, J.J. Davis and P.D. Beer, Chem. Commun. 2008, 3154-3156.

18. C.M.G. dos Santos, T. McCabe, G.W. Watson, P.E. Kruger and T. Gunnlaugsson, J. Org. Chem. 2008, 73, 9235-9244.

19. M.J. Hynes, J. Chem. Soc. Dalton Trans. 1993, 311-312. 